\title{
Wilms tumor protein recognizes 5-carboxylcytosine within a specific DNA sequence
}

\author{
Hideharu Hashimoto, ${ }_{1}$ Yusuf Olatunde Olanrewaju, ${ }^{1}$ Yu Zheng, ${ }^{2}$ Geoffrey G. Wilson, ${ }^{2}$ Xing Zhang, ${ }^{1}$ \\ and Xiaodong Cheng ${ }^{1}$
}

${ }^{1}$ Department of Biochemistry, Emory University School of Medicine, Atlanta, Georgia 30322, USA; ${ }^{2}$ New England Biolabs, Ipswich, Massachusetts 01938, USA

In mammalian DNA, cytosine occurs in several chemical forms, including unmodified cytosine (C), 5methylcytosine $(5 \mathrm{mC}), 5$-hydroxymethylcytosine $(5 \mathrm{hmC}), 5$-formylcytosine $(5 \mathrm{fC})$, and 5 -carboxylcytosine $(5 \mathrm{caC})$. $5 \mathrm{mC}$ is a major epigenetic signal that acts to regulate gene expression. $5 \mathrm{hmC}, 5 \mathrm{fC}$, and $5 \mathrm{caC}$ are oxidized derivatives that might also act as distinct epigenetic signals. We investigated the response of the zinc finger DNAbinding domains of transcription factors early growth response protein 1 (Egr1) and Wilms tumor protein 1 (WT1) to different forms of modified cytosine within their recognition sequence, 5'-GCG(T/G)GGGCG-3'. Both displayed high affinity for the sequence when $\mathrm{C}$ or $5 \mathrm{mC}$ was present and much reduced affinity when $5 \mathrm{hmC}$ or $5 \mathrm{fC}$ was present, indicating that they differentiate primarily oxidized $\mathrm{C}$ from unoxidized $\mathrm{C}$, rather than methylated $\mathrm{C}$ from unmethylated C. $5 \mathrm{caC}$ affected the two proteins differently, abolishing binding by Egr1 but not by WT1. We ascribe this difference to electrostatic interactions in the binding sites. In Egr1, a negatively charged glutamate conflicts with the negatively charged carboxylate of $5 \mathrm{caC}$, whereas the corresponding glutamine of WT1 interacts with this group favorably. Our analyses shows that zinc finger proteins (and their splice variants) can respond in modulated ways to alternative modifications within their binding sequence.

[Keywords: 5-carboxylcytosine; DNA modification; epigenetics]

Supplemental material is available for this article.

Received August 10, 2014; revised version accepted September 2, 2014.

In eukaryotic genomes, DNA methyltransferases convert a proportion of the cytosines (Cs), primarily in CpG dinucleotides, into 5-methylcytosine $(5 \mathrm{mC})$ (Bestor et al. 1988; Okano et al. 1998). Ten-eleven translocation (Tet) dioxygenases then convert a fraction of these to 5-hydroxymethylcytosine $(5 \mathrm{hmC}), 5$-formylcytosine $(5 \mathrm{fC})$, and 5carboxylcytosine $(5 \mathrm{caC})$ in consecutive oxidation reactions (Kriaucionis and Heintz 2009; Tahiliani et al. 2009; Globisch et al. 2010; Ito et al. 2010, 2011; He et al. 2011). These modifications protrude into the major groove of DNA, the primary recognition surface for proteins, and change its atomic shape and pattern of electrostatic charge. In principle, such changes can alter the way in which proteins bind to their recognition sequences in DNA by strengthening the interactions, weakening them, or abolishing them altogether. This, in turn, can modulate gene expression and control cellular metabolism and is believed to be one of the principal mechanisms underlying epigenetic processes such as differentiation, development, aging, and disease.

Corresponding author: xcheng@emory.edu

Article published online ahead of print. Article and publication date are online at http://www.genesdev.org/cgi/doi/10.1101/gad.250746.114. Freely available online through the Genes \& Development Open Access option.
Three well-characterized classes of mammalian proteins interact with DNA in a methylation-dependent manner. Methyl-binding domains (MBDs) recognize fully methylated CpG sequences in which both DNA strands contain 5mC (Baubec et al. 2013). SET and RING fingerassociated (SRA) domains recognize hemimethylated CpG sequences containing $5 \mathrm{mC}$ in only one strand, such as arise during DNA replication (Bostick et al. 2007; Sharif et al. 2007). In addition, certain Cys2-His2 (C2H2) zinc finger $(\mathrm{ZnF})$ proteins bind preferentially to longer, specific DNA sequences when internal CpG sites are methylated (Sasai et al. 2010; Liu et al. 2013b). The ability of ZnF proteins to respond to methylation in this way is significant because "sequences longer than $\mathrm{CpG}$ would be necessary for the regulation of gene expression by methylation" (Holliday 1996). The structures of three $\mathrm{ZnF}$ domains bound to 5mC-containing DNA were solved recently from the transcription factors Kaiso, Zfp57, and Klf4 (Buck-Koehntop et al. 2012; Liu et al. 2012, 2014). Here

(C) 2014 Hashimoto et al. This article, published in Genes \& Development, is available under a Creative Commons License (Attribution 4.0 International), as described at http://creativecommons.org/licenses/by/4.0. 
we investigate the binding of $\mathrm{ZnF}$ domains to oxidized modifications of $5 \mathrm{mC}$.

In conventional $\mathrm{C} 2 \mathrm{H} 2 \mathrm{ZnF}$ proteins, each finger comprises two $\beta$ strands and one helix and generally interacts with three adjacent DNA base pairs (Wolfe et al. 2000; Klug 2010). Amino acid side chains from the N-terminal portion of the helix together with the preceding residue make major groove contacts with the bases of primarily one DNA strand. Almost always, the first zinc-binding histidine is positioned in the middle of the helix, separated from the preceding cysteine by 12 residues. In the discussion below, we use this histidine as reference position 0 and number the residues that make base contacts from this rather than from the more variable first position of the $\alpha$ helix. Most commonly, proceeding leftward in the amino acid sequence toward the $\mathrm{N}$ terminus, residues at positions $-1,-4$, and -7 (or -8 ) make base-specific contacts through their side chains; the identities of these amino acids are the principle determinants of the DNA sequence recognized (Supplemental Fig. S1A), although by no means the only ones (Gupta et al. 2014; Persikov and Singh 2014).

Zfp57 (with two ZnFs in tandem) and Klf4 (with three) recognize the triplet 5'-G-5mC-G-3' within a 6-base-pair (bp) (Quenneville et al. 2011) and a 9-bp (Chen et al. 2008) sequence, respectively. In Zfp57 (Liu et al. 2012), arginine (R) at position -1 contacts the 5 ' guanine (Gua), glutamate (E) at -4 interacts with the $5 \mathrm{mC}$, and $\mathrm{R}$ at -8 contacts the 3' Gua (Supplemental Fig. S1A). Similar interactions occur with Klf4 (Liu et al. 2014), except that the 3' Gua is contacted by $\mathrm{R}$ at -7 rather than -8 (Supplemental Fig. S1A). Although predicting the binding of ZnFs to modified DNA remains a challenge, we found that four $\mathrm{ZnFs}$ from two other transcription factors, early growth response protein 1 (Egr1; also known as Zif268) and Wilms tumor protein 1 (WT1), also recognize DNA sequences containing 5'-GCG3' (Supplemental Fig. S1A). All four fingers have $\mathrm{R}$ at positions -1 and -7 ; three have $\mathrm{E}$ at -4 , and one (in WT1) has glutamine (Q) at position -4 instead (Supplemental Fig. S1A). We investigated the behavior of Egr1 and WT1 toward sequences containing all forms of modified $\mathrm{C}$ and report our findings here.

\section{Results}

Egr1/Zif268 belongs to a group of early response proteins whose genes are dramatically and rapidly induced upon stimulation by many environmental signals, including growth factors, hormones, and neurotransmitters (Pagel and Deindl 2011). The three-finger-binding domain of Egr1/Zif268 (Supplemental Fig. S1B) is one of the beststudied $\mathrm{C} 2 \mathrm{H} 2 \mathrm{ZnF}$ proteins structurally (Pavletich and Pabo 1991). It binds to the consensus sequence $5^{\prime}$ GCG(T/G)GGGCG-3' and has been used as a framework for engineering novel DNA-binding specificities (Wolfe et al. 2000; Klug 2010). This sequence contains two CpG sites for $\mathrm{C}$ modification that are dynamically modified in mouse embryonic stem cells (see the Supplemental Material). WT1, encoded by a complex gene characterized by many isoforms (Hohenstein and Hastie 2006; Ozdemir and
Hohenstein 2014), contains four C2H2 ZnFs (Supplemental Fig. S1C). The first of these does not contact the bases (Stoll et al. 2007) and contributes little to specificity (Hamilton et al. 1995; Nakagama et al. 1995). Consequently, WT1 binds the same consensus sequence as Egr1/Zif268 (Stoll et al. 2007) and, in some cases, antagonizes Egr1/Zif268 function (Ritchie et al. 2010). For the work described here, we used a construct of WT1 containing only $\mathrm{ZnF} 2$ through $\mathrm{ZnF} 4$, which was structurally analogous to Egr1/Zif268. We compared the binding affinities and the crystal structures of the two protein domains with the same DNA sequences.

\section{$5 m C$ substrates}

We compared the binding of Egr1/Zif268 and WT1 with unmodified and $5 \mathrm{mC}$-modified consensus sequences. Fluorescence polarization was used to measure the dissociation constant $\left(K_{\mathrm{D}}\right)$ between the two binding domains and double-stranded oligonucleotides (oligos) that were either unmethylated $(\mathrm{C} / \mathrm{C})$ or fully methylated $(\mathrm{M} / \mathrm{M})$ at both internal CpG dinucleotide sites. Egr1/Zif268 and WT1 showed slightly higher affinity for the fully methylated sequence by factors of $\sim 2.8$ (Egr1) and $\sim 1.8$ (WT1) (Fig. 1A,B). With these ZnFs, only one DNA strand is involved in base-specific contacts (the "top" strand, the one depicted as the recognition sequence), while the other strand interacts mainly with water molecules (Supplemental Figs. S2, S3). We replaced the two $5 \mathrm{mC}$ bases in the top strand with unmodified C. Affinity for this hemimethylated $(\mathrm{C} / \mathrm{M})$ sequence dropped by factors of $\sim 2$ (Egr1) and $\sim 1.2$ (WT1) (Fig. 1A,B) to values intermediate between those of the completely methylated and the completely unmodified sequences. These results indicate that $5 \mathrm{mC}$ methylation of the $\mathrm{CpG}$ dinucleotides within the consensus sequence enhances the binding affinity of Egr1 and WT1 only modestly.

\section{Oxidized $5 \mathrm{mC}$ substrates}

In turn, we replaced the two $5 \mathrm{mC}$ bases in the top strand with all three oxidized modifications $(5 \mathrm{hmC}, 5 \mathrm{fC}$, and $5 \mathrm{caC}$ ) and repeated the binding assays. $5 \mathrm{mC}$ was present in the bottom strand in each case. For Egr1/Zif268, oxidation reduced binding significantly for $5 \mathrm{hmC}$ (by a factor of $\sim 24$ compared with the $M / M$ substrate) and abolished it completely for $5 \mathrm{fC}$ and $5 \mathrm{caC}$ (Fig. 1C). For WT1, oxidation reduced binding significantly but did not abolish it in any instance. $5 \mathrm{hmC}$ and $5 \mathrm{fC}$ reduced affinity by a factor of $\sim 75 ; 5 \mathrm{caC}$ reduced it less, by a factor of $\sim 25$ (Fig. 1D). In contrast to Egr1, which cannot bind to $5 \mathrm{fC}$ or $5 \mathrm{caC}$, WT1 retained substantial affinity for these modifications, particularly for $5 \mathrm{caC}$ $\left(K_{\mathrm{D}}>2.3 \mu \mathrm{M}\right)$ (Fig. 1D).

\section{Asymmetrically modified substrates}

We next analyzed the effect of oxidized C at only the $3^{\prime}$ GCG triplet. $5 \mathrm{mC}$ was present in the bottom strand, as before, and also in both strands of the 5' GCG triplet. Egr1 exhibited progressively weaker binding to the oxidized 

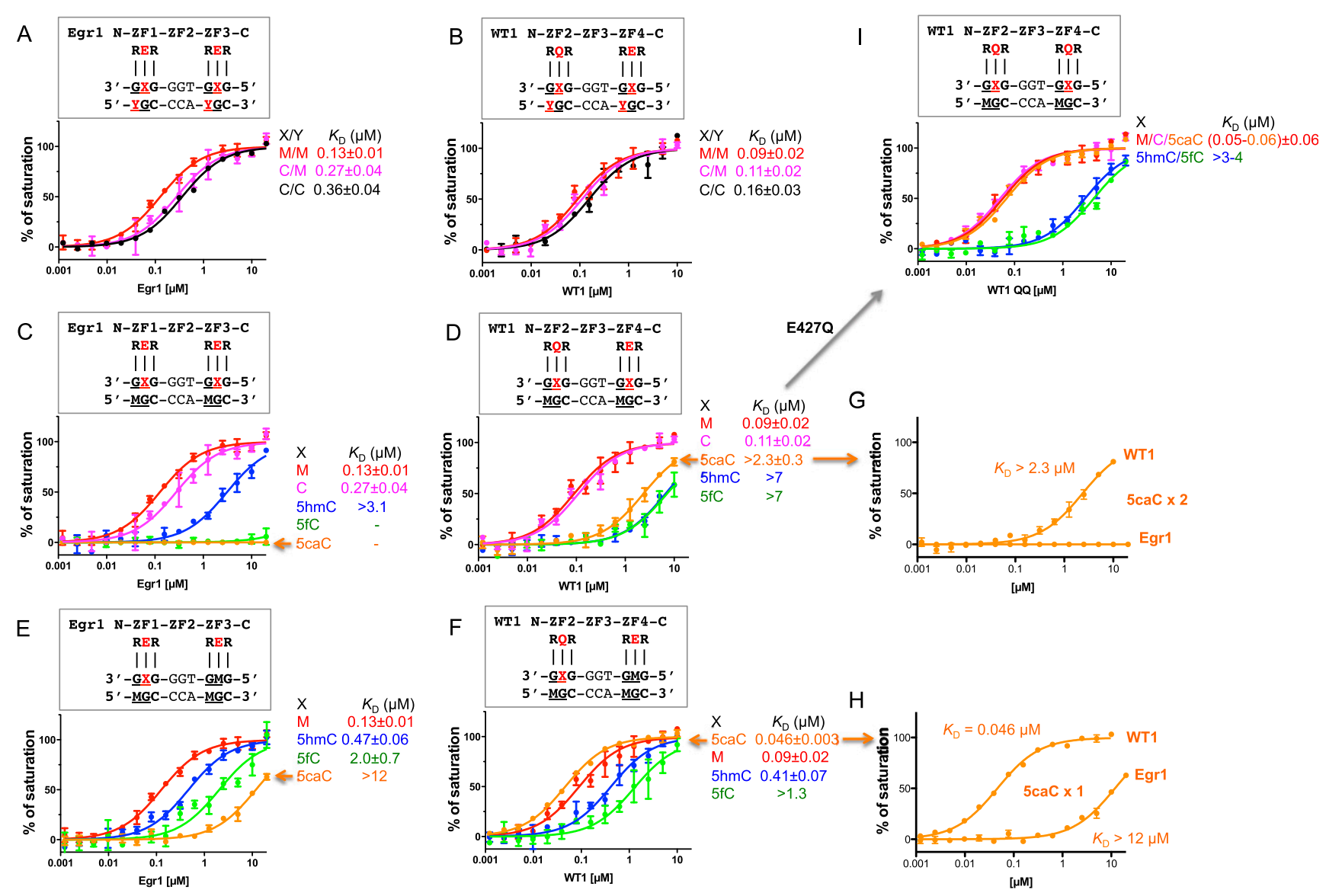

Figure 1. Egr1/Zif268 and WT1 bind methylated and 5mC oxidized DNA. Binding affinities of Egr1/Zif268 and WT1 with oligos containing varied forms of cytosine, as measured by fluorescence polarization assays. $(A, B)$ Oligos fully methylated at both sites $(\mathrm{M} / \mathrm{M})$, unmethylated at both sites $(\mathrm{C} / \mathrm{C})$, or methylated in only the bottom strand at both sites $(\mathrm{C} / \mathrm{M})$. $(C, D)$ Oligos modified in only the top strand at both sites with $5 \mathrm{mC}(\mathrm{M}), \mathrm{C}, 5 \mathrm{hmC}, 5 \mathrm{fC}$, or $5 \mathrm{caC} .5 \mathrm{mC}$ was present in the bottom strand at both sites in all cases. (E, F) Oligos modified in only the top strand at the $3^{\prime}$ site. All other sites contained $5 \mathrm{mC}(\mathrm{M}) .(G, H)$ Comparison of Egr1 and WT1 with oligos containing $5 \mathrm{caC}$ in the top strand at both sites $(5 \mathrm{caCx} 2)$ or only the 3 ' site $(5 \mathrm{caCx} 1)$ using the data from $C-F$. (I) The "QQ" variant (Q369 and $\mathrm{E} 427 \mathrm{Q}$ ) of WT1 displays enhanced binding with $5 \mathrm{caCx} 2$ oligos.

forms: $5 \mathrm{hmC}$ (3.6-fold lower than $5 \mathrm{mC})$, $5 \mathrm{fC}(15$-fold lower), and $5 \mathrm{caC}$ ( $>90$-fold lower) (Fig. 1E). WT1 behaved similarly for $5 \mathrm{hmC}(4.5$-fold lower than $5 \mathrm{mC})$ and $5 \mathrm{fC}(14-$ fold lower) but, in striking contrast to Egrl, bound more strongly (twofold higher) to $5 \mathrm{caC}$ than to $5 \mathrm{mC}$. The affinity of Egrl for this site is thus $5 \mathrm{mC}>5 \mathrm{hmC}>5 \mathrm{fC}>$ $5 \mathrm{caC}$, whereas for WT1, it is $5 \mathrm{caC}>5 \mathrm{mC}>5 \mathrm{hmC}>5 \mathrm{fC}$ (Fig. 1F).

\section{Differential ZnF affinities}

Comparing affinities for one-site and two-site modifications (Fig. 1G,H) indicates that the $\mathrm{N}$-terminal $\mathrm{ZnF} 2$ of WT1 (which interacts with the 3' GCG) has the highest affinity for $5 \mathrm{caC}\left(K_{\mathrm{D}} \sim 50 \mathrm{nM}\right)$, while the C-terminal ZnF4 (which interacts with the 5' GCG) and both of those of Egrl have the lowest affinity for $5 \mathrm{caC}\left(K_{\mathrm{D}}>12 \mu \mathrm{M}\right)$. This imbalance, we surmise, results in an intermediate affinity of $\sim 2.3 \mu \mathrm{M}$ for WT1 toward sequences containing $5 \mathrm{caC}$ at both positions ( $5 \mathrm{caCx} 2 \mathrm{DNA})$. The principle difference between the two WT1 ZnFs is the residue at position -4 , which is $\mathrm{E}$ in the low-affinity $\mathrm{ZnF} 4$ and $\mathrm{Q}$ in the high-affinity ZnF2. We used site-specific mutagenesis to change the $\mathrm{E}$ at position -4 of $\mathrm{ZnF} 4$ to $\mathrm{Q}$ (E427Q). The double "QQ" variant, as expected, now exhibited a higher affinity for the $5 \mathrm{caCx} 2$ sequence, although not markedly higher than for sequences containing $\mathrm{C}$ or $5 \mathrm{mC}$ (Fig. 1I). Affinity for DNA containing $5 \mathrm{hmCx} 2$ or $5 \mathrm{fCx} 2$ was little changed (Fig. 1I). In contrast to WT1 (QE) and the QQ mutant, Egr1 (the "EE" combination) has negligible affinity (no detectable binding) for 5caCx2 DNA (Fig. 1G).

\section{Structural investigations}

To understand why Egr1 and WT1 respond so differently to $5 \mathrm{caC}$, we determined the cocrystal structures of each protein with 10-bp oligos containing modified forms of the consensus sequence (Figs. 2, 3). We kept both strands of the 5' GCG triplet in an unmodified state and modified both strands of the 3' GCG triplet. We determined three structures for Egrl, with oligos containing $5 \mathrm{mC}, 5 \mathrm{hmC}$, and $5 \mathrm{fC}$ in the resolution range of $1.6-2.1 \AA$, and four 


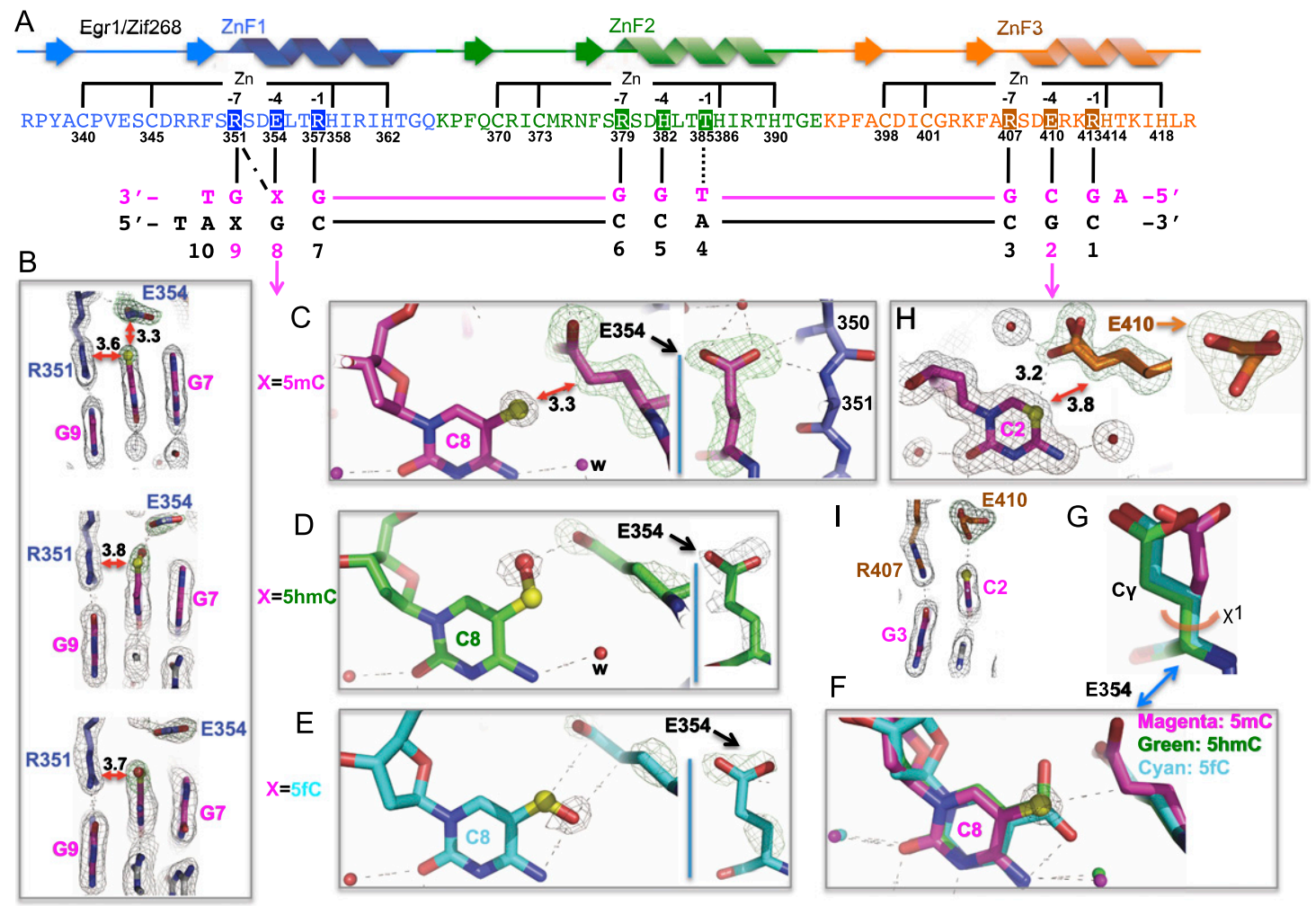

Figure 2. Egrl binds methylated and unmodified DNA. (A) Schematic representation of the ZnF1-3 DNA-binding domain of Egr1/ Zif268. The sequence and the secondary structure are shown. Arrows represent $\beta$ strands, lines represent loops, and ribbons represent $\alpha$ helices. Two cysteine and two histidine residues $(\mathrm{C} 2 \mathrm{H} 2)$ in each finger are responsible for $\mathrm{Zn}^{2+}$ ligand binding (top connecting lines). Amino acids at positions $-1,-4$, and -7 (highlighted) relative to the first histidine interact specifically with the DNA bases shown below. The sequence of the oligos used for this study is shown with the top strand (magenta) oriented left to right from $3^{\prime}$ to $5^{\prime}$ with a $5^{\prime}$ overhanging adenine. The complementary strand (black) has a $5^{\prime}$ overhanging thymine. $(B)$ Arg351 at position -7 of ZnF1 forms a methyl-Arg-Gua triad with the top strand of $\mathrm{XpG}(\mathrm{X}=5 \mathrm{mC}, 5 \mathrm{hmC}$, or $5 \mathrm{fC})$. The $2 \mathrm{Fo}-\mathrm{Fc}$ electron density, contoured at $1 \sigma$ above the mean, is shown in gray. (C) E354 at position -4 of $\mathrm{ZnF1}$ is in van der Waals contact with the methyl group of $5 \mathrm{mC}$ (red arrow; distance shown in angstroms). The simulated annealing omit electron densities (meshed lines), contoured at $10 \sigma$ and $4 \sigma$ above the mean, respectively, for omitting the methyl group of $5 \mathrm{mC}$ and the side chain of E354 are shown. $(D, E)$ The side chain of E354 becomes disordered with $5 \mathrm{hmC}(D)$ or $5 \mathrm{fC}(E)$. (E) An intrabase H-bond is present between the formyl oxygen of $5 \mathrm{fC}$ and the $\mathrm{N} 4$ group. Simulated annealing omit electron densities (meshed lines), contoured at $10 \sigma$ and $4 \sigma$ above the mean, respectively, for omitting the hydroxyl group of $5 \mathrm{hmC}(D)$ (or the carbonyl oxygen atom of $5 \mathrm{fC}[E)]$ and the side chain of E354 are shown. $(F, G)$ Conformation of E354 indicates $\sim 90^{\circ}$ side chain rotations with $5 \mathrm{hmC}$ (green) and $5 \mathrm{fC}$ (cyan) compared with $5 \mathrm{mC}$ (magenta). (H,I) E410 at position -4 of ZnF3 adopts two conformations with unmodified cytosine, engaging in van der Waals and weak C-H...O type H-bond interactions with the ring carbon atoms.

structures for WT1, with $5 \mathrm{mC}, 5 \mathrm{hmC}, 5 \mathrm{fC}$, and $5 \mathrm{caC}$ in the resolution range of 1.5-2.1 $\mathrm{\AA}$ (Supplemental Table S1). The three $\mathrm{ZnFs}$ of both proteins bind in the major DNA groove (Supplemental Figs. S2A, S3A). The Cterminal fingers (ZnF3 of Egrl and ZnF4 of WT1) interact with the $5^{\prime}$ triplet (GCG), the middle fingers (Egr1-ZnF2 and WT1-ZnF3) interact with the central triplet (TGG), and the N-terminal fingers (Egr1-ZnF1 and WT1-ZnF2) interact with the $3^{\prime}$ triplet (modified GCG) (Supplemental Figs. S2, S3).

In Egrl, the methyl group of $5 \mathrm{mC}$ in the top strand makes van der Waals contact with the side chain guanidino group of R351 at position -7 of $\mathrm{ZnF1}$ (Fig. 2A), which forms two hydrogen bonds (H-bonds) with the 3' Gua (Fig. 2B), forming a methyl-Arg-Gua triad (Liu et al. 2013b). The methyl group also makes van der Waals contacts with the $\mathrm{C} \gamma$ carbon atom of E354 (Fig. 2B,C), perpendic- ular to the methyl-Arg interaction. When the methyl group is oxidized to $5 \mathrm{hmC}$ or $5 \mathrm{fC}$, the side chain of E354 loses rigidity, as indicated by the broken electron densities (Fig. $2 \mathrm{D}, \mathrm{E})$, which might contribute toward the decreased binding affinity.

Superimposing the $5 \mathrm{mC}, 5 \mathrm{hmC}$, and $5 \mathrm{fC}$ structures revealed that $\mathrm{E} 354$ undergoes a significant change upon binding the oxidized modifications (Fig. 2F). Assuming that the broken density corresponds to the E354 side chain, the $\mathrm{C} \gamma$ atom moves away from the 5-methyl carbon by rotations of side chain torsion angles (Fig. 2G). In the $5 \mathrm{hmC}$ structure, the hydroxyl oxygen points away from the $\mathrm{N} 4$ amino group of $\mathrm{C}$ and interacts with the side chain carboxyl of E354 (Fig. 2D), whereas in the 5fC structure, the formyl oxygen points in the other direction and forms an intrabase H-bond with the $\mathrm{N} 4$ amino group (Fig. 2E). The latter interaction results in the exclusion of a water 


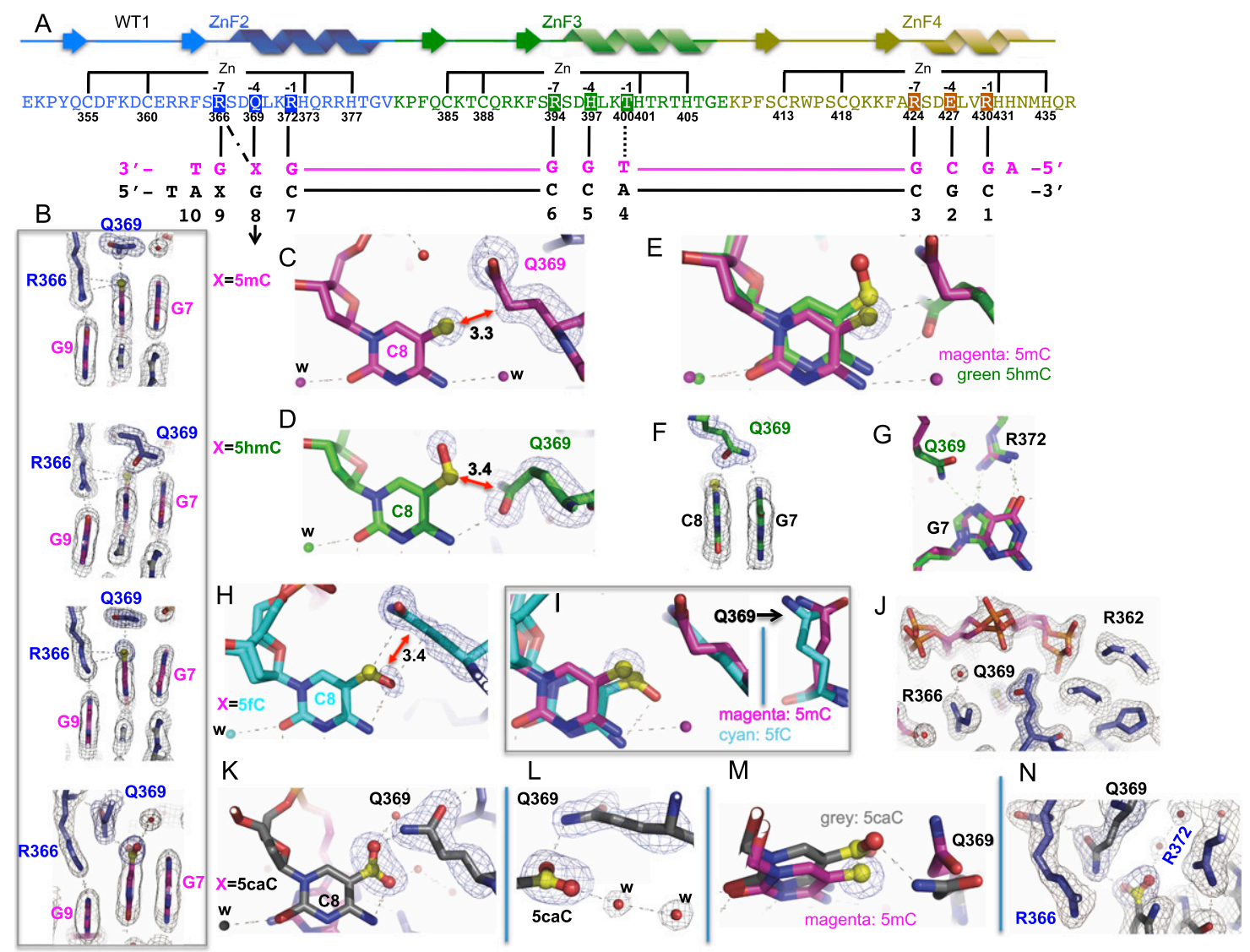

Figure 3. WT1 binds $5 \mathrm{caC}$ and $5 \mathrm{mC}$. (A) Schematic of ZnF2-ZnF4 DNA-binding domain WT1 (-KTS isoform), depicted as in Figure 2. (B) The side chain of Q369 at position -4 of $\mathrm{ZnF} 2$ adopts different conformations with (from top to bottom) $5 \mathrm{mC}, 5 \mathrm{hmC}, 5 \mathrm{fC}$, and $5 \mathrm{caC}$. The $2 \mathrm{Fo}-\mathrm{Fc}$ electron density, contoured at $1 \sigma$ above the mean, is shown in gray. $(C)$ Q369 is in van der Waals contact with the methyl group of $5 \mathrm{mC}$ (red arrow; distance in angstroms). The simulated annealing omit electron densities (meshed lines), contoured at $10 \sigma$ and $4 \sigma$ above the mean, respectively, for omitting the methyl group of $5 \mathrm{mC}$ and the side chain of Q369 are shown. (D) Q369 forms an $\mathrm{H}$-bond (dotted line) with the $\mathrm{N} 4$ atom of $5 \mathrm{hmC}$ and is in van der Waals contact (red arrow) with the $\mathrm{CH}_{2}$ group. (E) Superimposition of $C$ and $D$ showing side chain conformation of Q369 with $5 \mathrm{mC}$ (magenta) and $5 \mathrm{hmC}$ (green). The two conformations are related by rotations of $\chi^{1}=120^{\circ}, \chi^{2}=90^{\circ}$, and $\chi^{3}=90^{\circ}$. (F) Q369 interacts with 5hmC via the side chain carbonyl oxygen and with the 5' Gua via the amide group. $(G)$ R372 interaction with Gua7 in the presence of $5 \mathrm{mC}$ (magenta) and $5 \mathrm{hmC}$ (green). (H) Q369 interaction with $5 \mathrm{fC}$. An intrabase H-bond is present in 5fC as in Egr1 (Fig. 2E). (I) Superimposition of $C$ and $H$ showing side chain conformation of Q369 with $5 \mathrm{mC}$ (magenta) and $5 \mathrm{fC}$ (cyan). ( $J)$ The three phosphate groups immediately surrounding $5 \mathrm{fC}$ are mobile. $(K)$ One carboxylate oxygen of $5 \mathrm{caC}$ forms an H-bond with the side chain amide group of Q369. The other forms an intrabase H-bond with the N4 group. $(L)$ Watermediated interactions surrounding $5 \mathrm{caC}$ and Q369. The simulated annealing omit electron densities (meshed lines), contoured at 10 $\sigma$ and $4 \sigma$ above the mean, respectively, for omitting the carboxylate group of $5 \mathrm{caC}$ and the side chain of Q369 are shown. $(M)$ Superimposition of $C$ and $K$ showing Q369 with $5 \mathrm{mC}$ (magenta) and $5 \mathrm{caC}$ (gray). The two side chain conformations are related by a $70^{\circ}$ rotation of the $\chi 3$ torsion angle. $(N)$ Electrostatic sandwich between the negatively charged carboxylate group of $5 \mathrm{caC}$ and the positively charged guanidino groups R372 and R366.

molecule that is present in the $5 \mathrm{mC}$ and $5 \mathrm{hmC}$ structures but absent in the $5 \mathrm{fC}$ structure (Fig. 2C-E).

The interactions with unmodified $\mathrm{C}$ can be inferred from earlier cocrystal structures of Egr1/Zif268 (Supplemental Fig. S4; Pavletich and Pabo 1991) and from the C-terminal ZnF3 at the unmodified 5' GCG site (Fig. 2A). E410 at position -4 of ZnF3 adopts two slightly different side chain conformations. Both appear to be in van der Waals contact with ring carbon-5 of the C, and one might also form a weak (3.2 $\AA$ ) C-H. .O type bond with carbon-5 or carbon-6 (Fig. $2 \mathrm{H}_{\text {; Horowitz and }}$ Trievel 2012). The interaction corresponding to the methyl-Arg contact is absent, but some stacking be- tween the $\mathrm{C}$ ring and the side chain of Arg at position -7 continues (Fig. 2I).

For WT1, the higher binding affinity for $5 \mathrm{caC}$ allowed us to determine the structure of the complex with this modification in addition to those with the others. R366 at position -7 of WT1 ZnF2, like R351 of Egr1, forms H-bonds with the 3' Gua and van der Waals contacts with the $5 \mathrm{mC}, 5 \mathrm{hmC}$, and $5 \mathrm{fC}$ groups (Fig. $3 \mathrm{~B}$ ). The side chain of Q369 at position -4 contacts the methyl group of $5 \mathrm{mC}$ with a conformation similar to that of E354 of Egr1 (Fig. $3 \mathrm{C}$ ) but adopts a quite different conformation with $5 \mathrm{hmC}$ (Fig. 3D) and yet another conformation with $5 \mathrm{caC}$. Movement of Q369 from the conformation that it adopts 
with $5 \mathrm{mC}$ to that with $5 \mathrm{hmC}$ requires rotations of all three side chain torsion angles (Fig. 3E). Rather than interacting with the $5 \mathrm{hmC}$ hydroxyl, Q369 in this different conformation appears to form two $\mathrm{H}$-bonds with bases: one with the $\mathrm{N} 4$ amino group of $5 \mathrm{hmC}$ (via the side chain carbonyl oxygen) and the other with the N7 ring atom of the $5^{\prime}$ Gua (via the side chain amide group) (Fig. 3F). The latter H-bond weakens the interaction between Gua and R372 at position -1, pulling Gua closer and pushing R372 away (Fig. 3G). The water molecule mentioned previously is present in the $5 \mathrm{mC}$ structure but not in the $5 \mathrm{hmC}$ structure due to the different conformation of Q369 (Fig. 3C,D).

The Q369-5fC interaction in WT1 (Fig. 3H) is similar to the Q369-5mC interaction except for minor differences in side chain conformation (Fig. 3I). However, for reasons unclear to us, the three phosphate groups (two $5^{\prime}$ and one $3^{\prime}$ ) immediately surrounding $5 \mathrm{fC}$ can all be modeled with multiple conformations, indicating flexibility of the local DNA structure (Fig. 3J). This flexibility is not observed in the other WT1 structures (all of which crystallized in the same space group) or the Egrl structures with the same oligos.

The $5 \mathrm{caC}$ bound by WT1 participates in intramolecular and intermolecular interactions. An intrabase H-bond is present between the $\mathrm{N} 4$ amino group and one of the $5 \mathrm{caC}$ carboxylate oxygens (Fig. 3K). The second carboxylate oxygen atom forms an $\mathrm{H}$-bond with the amide of Q369 (Fig. $3 \mathrm{~K}, \mathrm{~L}$ ), the side chain of which has rotated $\sim 70^{\circ}$ around the $x^{3}$ torsion angle from the conformation in which it interacts with $5 \mathrm{mC}$ (Fig. $3 \mathrm{M}$ ). The negatively charged carboxylate group is also sandwiched between the positively charged guanidino groups of R372 and R366 that recognize the neighboring Guas (Fig. 3N). The $5 \mathrm{caC}$ carboxylate group is further stabilized by water-mediated interactions (Fig. 3L) that also involve the side chain of the adjacent amino acid, S365. The corresponding residue in $\mathrm{ZnF} 4, \mathrm{~A} 423$, cannot interact with water in this way, and this might explain why the affinity of the double "QQ" mutant E427Q for DNA containing $5 \mathrm{caC}$ at both positions is no greater than it is for DNA containing $\mathrm{C}$ or $5 \mathrm{mC}$ instead (Fig. 1I).

The WT1 + KTS (Lys-Thr-Ser) splice isoform binds most strongly to 5caC DNA

WT1 is encoded by a complex gene characterized by many isoforms (Hohenstein and Hastie 2006; Ozdemir and Hohenstein 2014). All known isoforms of WT1 include four $\mathrm{ZnFs}$ at the $\mathrm{C}$ terminus with or without three extra amino acids (KTS) between $\mathrm{ZnF3}$ and $\mathrm{ZnF} 4$ (Hohenstein and Hastie 2006; Ozdemir and Hohenstein 2014). Mutations in the splice site of WT1 that change the normal +KTS/-KTS ratio of 60:40 to 40:60 lead to Frasier syndrome (Barbaux et al. 1997). The preceding discussions pertain only to the - KTS isoform. We also expressed and purified the +KTS isoform in the context of $\mathrm{ZnF2-ZnF4}$ and compared the binding affinities of the two isoforms with variously modified substrates (Fig. 4A). The + KTS isoform has greatly reduced binding affinity for oligos containing unmodified C or 5mC (fully or hemimethylated) compared with the -KTS isoform by a factor of $\sim 24$ (Fig. 4B). This reduced affinity might result from increased linker flexibility due to the additional amino acids that leads to loss of binding by ZnF4 (Laity et al. $2000 \mathrm{~b})$. Both \pm KTS isoforms have a similar, relatively low, affinity for $5 \mathrm{caCx} 2$-containing DNA but substantially different (25-fold) affinities for 5mC-containing DNA (Fig. 4C). This suggests that the negative effect of E427 at position -4 of $\mathrm{ZnF} 4$ when juxtaposed to $5 \mathrm{caC}$ is about the same as losing binding by $\mathrm{ZnF} 4$ altogether. It also suggests that Frasier syndrome stems from perturbed binding at genomic sites that contain $\mathrm{C}$ or $5 \mathrm{mC}$ (by the increased amount of -KTS isoform) rather than at sites containing $5 \mathrm{caC}$ (owing to similar binding affinities for both isoforms). We found that the +KTS isoform with Q369 at position -4 binds most strongly to $5 \mathrm{caC}$-containing DNA with decreasing affinity in the order $5 \mathrm{caC}>$ $5 \mathrm{mC} \approx \mathrm{C}>5 \mathrm{hmC} \approx 5 \mathrm{fC}$ (Fig. 4D) and that the affinity increases markedly at lower salt concentrations (Fig. 4E).

\section{A WT1 mutant variant with high preference for $5 \mathrm{mC}$}

Finally, we were interested in variants that strongly distinguish only one modification. The engineered QQ variant of WT1 strongly distinguishes sequences containing $5 \mathrm{caC}, 5 \mathrm{mC}$, or $\mathrm{C}$ from those containing $5 \mathrm{hmC}$ or $5 \mathrm{fC}$ by a factor of 60 or more (Fig. 1I). Another variant that we examined (" $\mathrm{PP}^{\prime \prime}$ ) has proline at position -4 in WT1 ZnF2 and $\mathrm{ZnF} 4$ in place of Q369 and E427. This variant displayed a high preference for $5 \mathrm{mC}$ compared with both oxidized $\mathrm{C}$ and unmodified $\mathrm{C}$ by factors ranging from 40 to 140 (Fig. 5A). This result was somewhat surprising. We anticipated that proline in the first turn (the third residue) of the helices might destabilize them (Stoll et al. 2007) and abolish binding, but, evidently, they did not (Fig. 5B, C). The selectivity of the PP WT1 variant for $5 \mathrm{mC}$ compared with $\mathrm{C}$ stems not from an increase in affinity for $5 \mathrm{mC}$ but a $>100$-fold decrease in affinity for $\mathrm{C}$ (cf. Figs. $5 \mathrm{~A}$ and $1 \mathrm{D}$ ). Interestingly, the mismatch repair endonuclease MutH (Lee et al. 2005) also uses a proline to juxtapose a methyl group in its hemimethylated recognition sequence, one that occurs on adenine rather than on $\mathrm{C}$ in this case (Supplemental Fig. S5).

\section{Discussion}

Our results show that the binding domains of transcription factors Egr1 and WT1 are responsive to all forms of modified $\mathrm{C}$ within the recognition sequence. They display high affinity for sequences containing $\mathrm{C}$ and slightly higher affinity for sequences containing $5 \mathrm{mC}$ but much lower affinity for the sequences containing $5 \mathrm{hmC}$ or $5 \mathrm{fC}$. The two domains distinguish primarily unoxidized forms of $\mathrm{C}$ from oxidized forms, rather than the more familiar situation of unmethylated C from methylated C.

The most interesting aspect of our study concerns the $5 \mathrm{caC}$ modification. Put simply, when residue -4 is $\mathrm{E}$, sequences containing $5 \mathrm{caC}$ are bound the poorest, and when it is $\mathrm{Q}$, they are bound the best. When $\mathrm{E}$ juxtaposes 


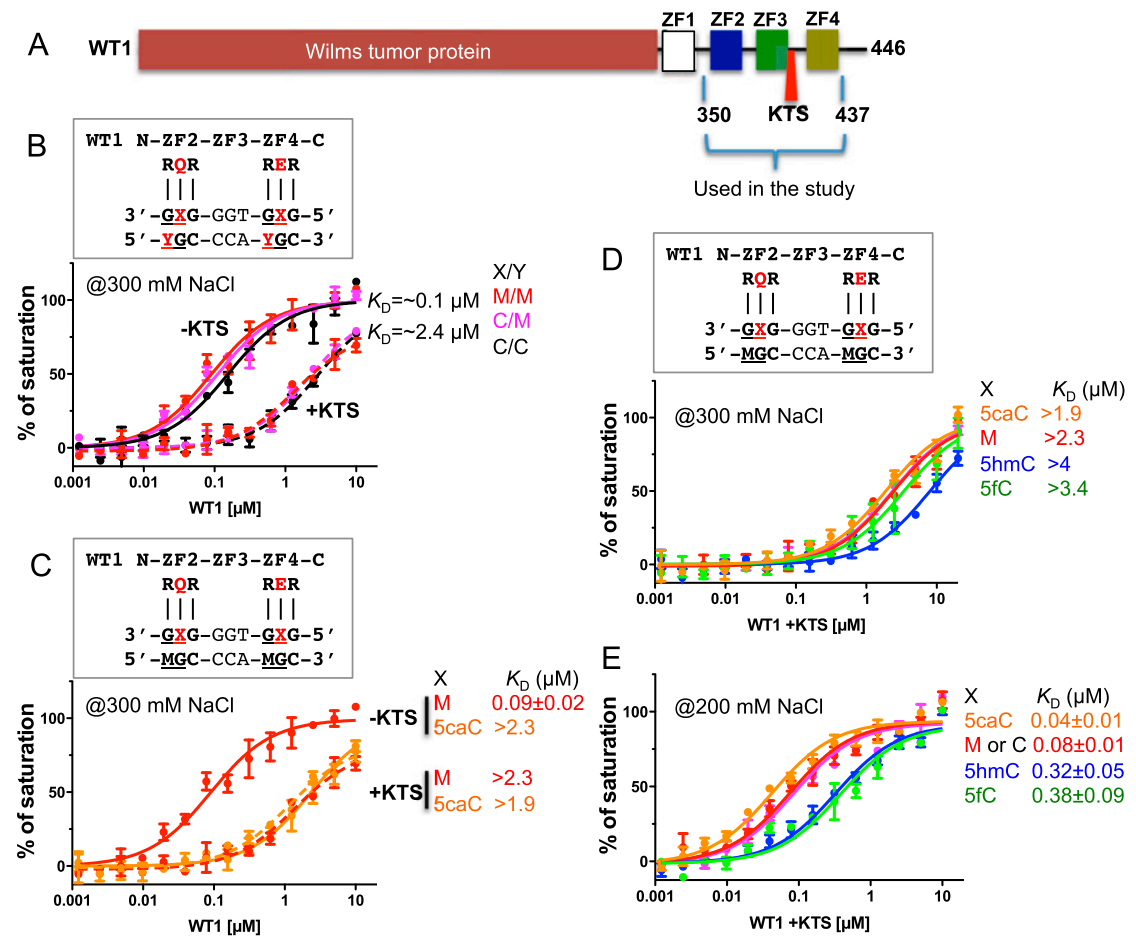

Figure 4. The WT1 +KTS isoform binds most strongly to $5 \mathrm{caC}$ DNA. (A) Human WT1 contains a C-terminal ZnF DNAbinding domain comprising four fingers in tandem. For the study described here, we used a fragment of WT1 containing $\mathrm{ZnF} 2, \mathrm{ZnF} 3$, and ZnF4 without KTS / the - KTS isoform) and with KTS (the +KTS isoform). (B) Comparison of the \pm KTS isoforms on oligos containing unmodified $\mathrm{C}$ or $5 \mathrm{mC}$ (fully or hemimethylated). (C) The two KTS isoforms have a similar, relatively low affinity for $5 \mathrm{caC}$-containing DNA but substantially different affinities for 5mC-containing DNA. $(D, E)$ The +KTS isoform binds most strongly to $5 \mathrm{caC}$-containing DNA. Affinity is uniformly low in $300 \mathrm{mM} \mathrm{NaCl}(D)$ but considerably higher in $200 \mathrm{mM} \mathrm{NaCl}(E)$.
$5 \mathrm{caC}$, both carboxylate groups bear a full -1 charge and thus repel one another electrostatically. We consider this the likeliest explanation for the very poor binding affinity of E:5caC combinations. In contrast, when $Q$ juxtaposes $5 \mathrm{caC}$, a strong $\mathrm{H}$-bond forms between the carboxylate and side chain amide groups, one that is likely augmented by electrostatic attraction. $5 \mathrm{caC}$ has the potential to function epigenetically to weaken binding by $\mathrm{ZnFs}$ with $\mathrm{E}$ at position -4 and strengthen binding by ZnFs with $\mathrm{Q}$ at position -4 .

Our analyses show that binding by Egr1 and WT1 is affected to different degrees depending on whether one or both sites are modified. Although the experiments were performed in vitro, they imply that $\mathrm{ZnF}$ transcription factors can respond in modulated ways to alternative modifications at different $\mathrm{C}$ positions. Because the Egr1WT1-binding sequence has two CpG sites, in principle, it can occur in 25 different states, with C, $5 \mathrm{mC}, 5 \mathrm{hmC}, 5 \mathrm{fC}$, or $5 \mathrm{caC}$ at either site. If the two DNA strands can be modified independently (i.e., strand-biased DNA modification) (Yu et al. 2012), then the number of different states could swell to $25^{2}$ (or 625). Many of these states could affect binding affinity, and so gene activity could plausibly be controlled on a much finer scale by these modifications than simply "on" or "off." This hints, perhaps, at new levels of subtlety and versatility in epigenetic regulatory processes. In the case of WT1, the splice variants add yet another layer of regulatory control (Fig. 4).

\section{Materials and methods}

Rather than following published methods of refolding insoluble WT1 ZnF1-4 (Laity et al. 2000a) and Egr1/Zif268 (Pavletich and Pabo 1991), we expressed and purified these proteins in soluble form by fusing the three-ZnF DNA-binding domains to gluta- thione S-transferase (GST). Because the published X-ray structure of WT1 has only $3.15 \AA$ resolution (Stoll et al. 2007), which is insufficient to discern the various $\mathrm{C}$ modifications, we sought a higher-resolution structure. We purified a construct comprising WT1 ZnF2-4 and determined its structure anew in complex with oligos containing various $\mathrm{C}$ modifications to final resolutions between 1.5 and $2.1 \AA$.

\section{Protein expression and purification}

GST-tagged human Egr1/Zif268 residues 335-423 (NP_001955.1) and human WT1 residues 401-488 (NP_000369.3; -KTS isoform) were separately cloned into pGEX6P-1, generating plasmids of pXC1272 and pXC1295. In addition, we generated two WT1 mutants (QQ variant, $\mathrm{pXC1335;} P \mathrm{P}$ variant, $\mathrm{pXC1320)}$ and the +KTS isoform (pXC1329). These were expressed in the Escherichia coli strain of BL21-CodonPlus(DE3)-RIL (Stratagene). Typically, 2-3 $\mathrm{L}$ of cultures were grown at $37^{\circ} \mathrm{C}$ to $\log$ phase $\left(\mathrm{OD}_{600} \sim 0.5-0.8\right)$ and then shifted to $16^{\circ} \mathrm{C}, \mathrm{ZnCl}_{2}$ was added to a final concentration of $25 \mu \mathrm{M}$, expression was induced by the addition of $\beta$-D-1-thiogalactopyranoside to $0.2 \mathrm{mM}$, and the cultures were incubated overnight at $16^{\circ} \mathrm{C}$. Cells were harvested by centrifugation; resuspended in lysis buffer containing $20 \mathrm{mM}$ Tris-HCl (pH 7.5), $250 \mathrm{mM} \mathrm{NaCl}$ (Egr1/Zif268) or $500 \mathrm{mM} \mathrm{NaCl}$ (WT1), 5\% (v/v) glycerol, $0.5 \mathrm{mM}$ Tris(2-carboxyethyl)phosphine hydrochloride (TCEP), and $25 \mu \mathrm{M} \mathrm{ZnCl}_{2}$; and lysed by sonication. Lysates were mixed with polyethylenimine (Sigma) at $\mathrm{pH} 7.0$ (adjusted by $\mathrm{NaOH}$ ) to a final concentration of $0.4 \%$ $(\mathrm{w} / \mathrm{v})$ before centrifugation at $18,000 \mathrm{rpm}$.

The cleared extract was loaded onto a glutathione-Sepharose 4B column (GE Healthcare) pre-equilibrated with lysis buffer (above). The GST fusion proteins were eluted with $20 \mathrm{mM}$ glutathione (GSH) in the elution buffer containing $100 \mathrm{mM}$ Tris- $\mathrm{HCl}(\mathrm{pH} 8.0), 5 \%(\mathrm{v} / \mathrm{v})$ glycerol, $25 \mu \mathrm{M} \mathrm{ZnCl}_{2}$, and 250 $\mathrm{mM} \mathrm{NaCl}$ (Egrl/Zif268) or $500 \mathrm{mM} \mathrm{NaCl}$ (WT1). The GST tag was removed using PreScission protease (purified in-house), leaving five additional N-terminal residues (Gly-Pro-Leu-Gly- 


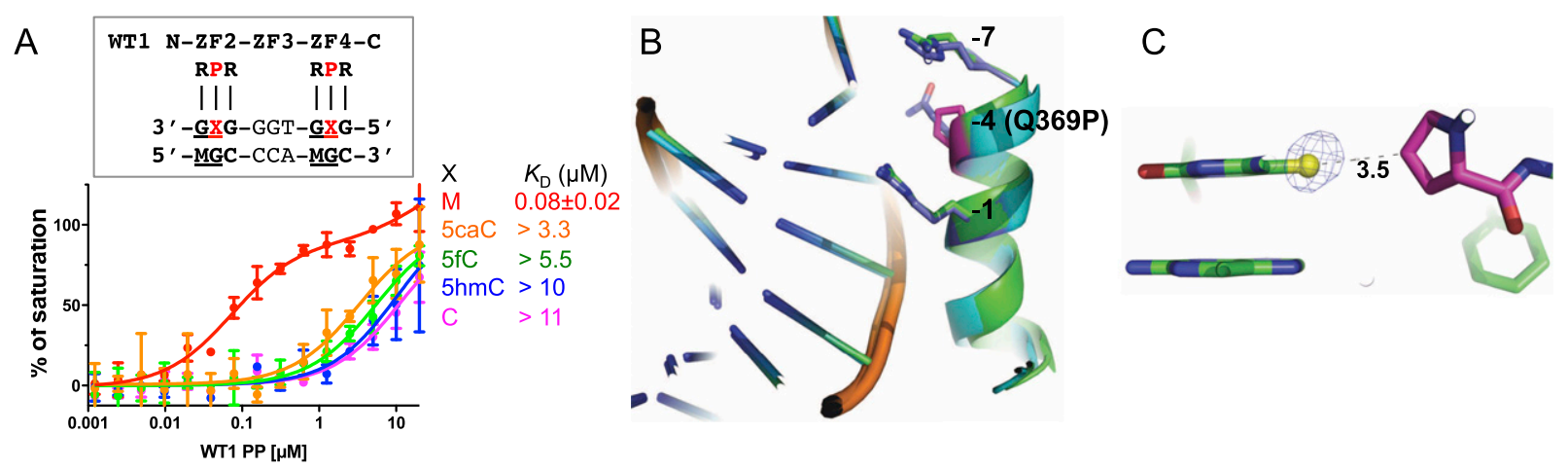

Figure 5. A WT1 mutant variant with high preference for 5mC. $(A)$ The "PP" variant (Q369P and E427P) of WT1 prefers $5 \mathrm{mC}$ to all other forms by a factor of 40-140. (B) Structural comparison of WT1 wild type and the Q369P mutant. (C) The methyl group of 5mC forms a van der Waals contact with the proline at -4 position. The simulated annealing omit electron density (blue lines), contoured at $4 \sigma$ above the mean, for omitting the methyl group of $5 \mathrm{mC}$ are shown.

Ser) on each protein. The proteins were diluted twofold with $20 \mathrm{mM}$ Tris- $\mathrm{HCl}(\mathrm{pH} 7.5)$, 5\% (v/v) glycerol, $25 \mu \mathrm{M} \mathrm{ZnCl} 2$, and $0.5 \mathrm{mM}$ TCEP and loaded onto tandem HiTrap-Q/HiTrap-SP columns (GE Healthcare). Most proteins flowed through the Q column onto the SP column from which it was eluted using a linear gradient of $\mathrm{NaCl}$ from $120 \mathrm{mM}$ to $1 \mathrm{M}$. Finally, the pooled protein was concentrated and loaded onto a size exclusion column and eluted as a single peak in $500 \mathrm{mM} \mathrm{NaCl}, 20 \mathrm{mM}$ Tris- $\mathrm{HCl}(\mathrm{pH} 7.5), 5 \%(\mathrm{v} / \mathrm{v})$ glycerol, and $25 \mu \mathrm{M} \mathrm{ZnCl} 2$. Final protein concentrations were estimated by absorbance at $280 \mathrm{~nm}$ for WT1 (absorbance coefficient of 9.66 for $1 \mathrm{mM} \mathrm{WT1)}$ or, for Egr1/Zif268, by Bradford protein assay (Bio-Rad no. 500-0205) using a mutant Zfp57 E182Y (Liu et al. 2013a) as a standard.

\section{Fluorescence-based DNA-binding assay}

Fluorescence polarization measurements were carried out at $25^{\circ} \mathrm{C}$ on a Synergy 4 microplate reader (BioTek). The 6-carboxy-fluorescein (FAM)-labeled dsDNA probe (5 nM) was incubated for $10 \mathrm{~min}$ with increasing amounts of protein in 300 $\mathrm{mM} \mathrm{NaCl}, 20 \mathrm{mM}$ Tris- $\mathrm{HCl}(\mathrm{pH} 7.5), 5 \%$ (v/v) glycerol, and 0.5 $\mathrm{mM}$ TCEP. No change in fluorescence intensity was observed with the addition of protein. The sequences of the oligonucleotides were FAM-5'-TAYGCCCAYGC-3' and $3^{\prime}$-TGXGGGTG XGA-5' (where $\mathrm{X}$ and $\mathrm{Y}=\mathrm{C}, 5 \mathrm{mC}, 5 \mathrm{hmC}, 5 \mathrm{fC}$, or $5 \mathrm{caC}$ as defined in Fig. 1). Curves were fit individually using GraphPad Prism 5.0 software (GraphPad Software, Inc.). Binding constants $\left(K_{\mathrm{D}}\right)$ were calculated as $[m P]=[$ maximum $m P] \times[C] /\left(K_{\mathrm{D}}+[C]\right)+$ [baseline $m P]$, and saturated $[\mathrm{mP}]$ was calculated as saturation $=$ $([m P]-[$ baseline $m P]) /([$ maximum $m P]-[$ baseline $m P])$, where $\mathrm{mP}$ is millipolarization and $[C]$ is protein concentration. Averaged $K_{\mathrm{D}}$ and its standard error are reported.

\section{Crystallography}

We crystallized Egr1/Zif268 (or WT1) in the presence of DNA by the sitting-drop vapor diffusion method at $16^{\circ} \mathrm{C}$ using equal amounts of protein-DNA mixtures $(1 \mathrm{mM})$ and well solution (Supplemental Table S2). Protein-DNA mixtures in equimolar ratios were incubated for $30 \mathrm{~min}$ at $16^{\circ} \mathrm{C}$ before crystallization. Crystals were cryoprotected by soaking in mother liquor supplemented with $20 \%$ (v/v) ethylene glycol or $20 \%$ (v/v) glycerol before plunging into liquid nitrogen.

X-ray diffraction data sets were collected at $100 \mathrm{~K}$ at the SERCAT beamlines (22BM-E and 22ID-D) at the Advanced Photon Source, Argonne National Laboratory, and processed using
HKL2000 (Otwinowski et al. 2003). Initial crystallographic phases were determined by molecular replacement using the coordinates of the DNA-binding domains of human Egr1/Zif268 (Protein Data Bank [PDB]: 1AAY) (Elrod-Erickson et al. 1996) and WT1 (PDB: 2PRT) (after deleting ZnF1) (Stoll et al. 2007) as search models, respectively (Supplemental Figs. S2, S3). Phasing, molecular replacement, map production, and model refinement were performed using PHENIX (Adams et al. 2010). All eight structures were solved, built, and refined independently. The statistics were calculated for the entire resolution range (Supplemental Table S1). The $R_{\text {free }}$ and $R_{\text {work }}$ values were calculated for $5 \%$ (randomly selected) and $95 \%$, respectively, of the observed reflections. Molecular graphics were generated using PyMol (DeLano Scientific, LLC).

\section{Accession numbers}

The X-ray structures (coordinates and structure factor files) of Egr1/Zif268 (4R2A for $5 \mathrm{mC}, 4 \mathrm{R} 2 \mathrm{C}$ for $5 \mathrm{hmC}$, and $4 \mathrm{R} 2 \mathrm{D}$ for $5 \mathrm{fC}$ ), WT1 (4R2E for $5 \mathrm{mC}$, 4R2P for $5 \mathrm{hmC}$, 4R2Q for $5 \mathrm{fC}$, and 4R2R for $5 \mathrm{caC}$ ), and WT1 mutant Q369P in complex with $5 \mathrm{mC}$ DNA (4R2S) have been submitted to PDB.

\section{Acknowledgments}

We thank B. Baker for synthesizing the oligonucleotides, R.J. Roberts for comments, and P.M. Vertino and L.R. Souza for discussion. The Department of Biochemistry of Emory University School of Medicine supported the use of SER-CAT beamlines at the Advanced Photon Source, Argonne National Laboratory. This work was supported by National Institutes of Health grant GM049245-21 to X.C. (who is a Georgia Research Alliance Eminent Scholar). H.H. performed crystallographic and DNA-binding experiments, Y.O.O. performed protein purification, Y.Z. analyzed published sequence data, G.G.W. performed structural analysis and assisted in preparing the manuscript, X.Z. and X.C. organized and designed the scope of the study, and all were involved in analyzing data and preparing the manuscript.

\section{References}

Adams PD, Afonine PV, Bunkoczi G, Chen VB, Davis IW, Echols N, Headd JI, Hung LW, Kapral GJ, Grosse-Kunstleve RW, et al. 2010. PHENIX: a comprehensive Python-based system for macromolecular structure solution. Acta Crystallogr D Biol Crystallogr 66: 213-221. 
Barbaux S, Niaudet P, Gubler MC, Grunfeld JP, Jaubert F, Kuttenn F, Fekete CN, Souleyreau-Therville N, Thibaud E, Fellous M, et al. 1997. Donor splice-site mutations in WT1 are responsible for Frasier syndrome. Nat Genet 17: 467-470.

Baubec T, Ivanek R, Lienert F, Schubeler D. 2013. Methylationdependent and -independent genomic targeting principles of the MBD protein family. Cell 153: 480-492.

Bestor T, Laudano A, Mattaliano R, Ingram V. 1988. Cloning and sequencing of a cDNA encoding DNA methyltransferase of mouse cells. The carboxyl-terminal domain of the mammalian enzymes is related to bacterial restriction methyltransferases. J Mol Biol 203: 971-983.

Bostick M, Kim JK, Esteve PO, Clark A, Pradhan S, Jacobsen SE. 2007. UHRF1 plays a role in maintaining DNA methylation in mammalian cells. Science 317: 1760-1764.

Buck-Koehntop BA, Stanfield RL, Ekiert DC, Martinez-Yamout MA, Dyson HJ, Wilson IA, Wright PE. 2012. Molecular basis for recognition of methylated and specific DNA sequences by the zinc finger protein Kaiso. Proc Natl Acad Sci 109: 15229-15234.

Chen X, Xu H, Yuan P, Fang F, Huss M, Vega VB, Wong E, Orlov $\mathrm{YL}$, Zhang $\mathrm{W}$, Jiang $\mathrm{J}$, et al. 2008. Integration of external signaling pathways with the core transcriptional network in embryonic stem cells. Cell 133: 1106-1117.

Elrod-Erickson M, Rould MA, Nekludova L, Pabo CO. 1996. Zif268 protein-DNA complex refined at $1.6 \mathrm{~A}$ : a model system for understanding zinc finger-DNA interactions. Structure 4: 1171-1180.

Globisch D, Munzel M, Muller M, Michalakis S, Wagner M, Koch S, Bruckl T, Biel M, Carell T. 2010. Tissue distribution of 5-hydroxymethylcytosine and search for active demethylation intermediates. PLOS ONE 5: e15367.

Gupta A, Christensen RG, Bell HA, Goodwin M, Patel RY, Pandey M, Enuameh MS, Rayla AL, Zhu C, ThibodeauBeganny S, et al. 2014. An improved predictive recognition model for Cys2-His2 zinc finger proteins. Nucleic Acids Res 42: 4800-4812.

Hamilton TB, Barilla KC, Romaniuk PJ. 1995. High affinity binding sites for the Wilms' tumour suppressor protein WT1. Nucleic Acids Res 23: 277-284.

He YF, Li BZ, Li Z, Liu P, Wang Y, Tang Q, Ding J, Jia Y, Chen Z, $\mathrm{Li}$ L, et al. 2011. Tet-mediated formation of 5-carboxylcytosine and its excision by TDG in mammalian DNA. Science 333: $1303-1307$.

Hohenstein P, Hastie ND. 2006. The many facets of the Wilms tumour gene, WT1. Hum Mol Genet 15: R196-R201.

Holliday R. 1996. DNA methylation in eukaryotes: 20 years on. In Epigenetic mechanisms of gene regulation (ed. Russo VEA, et al.), pp. 5-27. Cold Spring Harbor Laboratory Press, Cold Spring Harbor, NY.

Horowitz S, Trievel RC. 2012. Carbon-oxygen hydrogen bonding in biological structure and function. J Biol Chem 287: 4157641582.

Ito S, D'Alessio AC, Taranova OV, Hong K, Sowers LC, Zhang Y. 2010. Role of Tet proteins in $5 \mathrm{mC}$ to $5 \mathrm{hmC}$ conversion, EScell self-renewal and inner cell mass specification. Nature 466: 1129-1133.

Ito S, Shen L, Dai Q, Wu SC, Collins LB, Swenberg JA, He C, Zhang Y. 2011. Tet proteins can convert 5-methylcytosine to 5-formylcytosine and 5-carboxylcytosine. Science 333: 13001303.

Klug A. 2010. The discovery of zinc fingers and their applications in gene regulation and genome manipulation. Annu Rev Biochem 79: 213-231.
Kriaucionis S, Heintz N. 2009. The nuclear DNA base 5hydroxymethylcytosine is present in Purkinje neurons and the brain. Science 324: 929-930.

Laity JH, Chung J, Dyson HJ, Wright PE. 2000a. Alternative splicing of Wilms' tumor suppressor protein modulates DNA binding activity through isoform-specific DNA-induced conformational changes. Biochemistry 39: 5341-5348.

Laity JH, Dyson HJ, Wright PE. 2000b. Molecular basis for modulation of biological function by alternate splicing of the Wilms' tumor suppressor protein. Proc Natl Acad Sci 97: 11932-11935.

Lee JY, Chang J, Joseph N, Ghirlando R, Rao DN, Yang W. 2005. MutH complexed with hemi- and unmethylated DNAs: coupling base recognition and DNA cleavage. Mol Cell 20: 155-166.

Liu Y, Toh H, Sasaki H, Zhang X, Cheng X. 2012. An atomic model of Zfp57 recognition of CpG methylation within a specific DNA sequence. Genes Dev 26: 2374-2379.

Liu Y, Olanrewaju YO, Zhang X, Cheng X. 2013a. DNA recognition of 5-carboxylcytosine by a Zfp57 mutant at an atomic resolution of $0.97 \mathrm{~A}$. Biochemistry 52: 9310-9317.

Liu Y, Zhang X, Blumenthal RM, Cheng X. 2013b. A common mode of recognition for methylated CpG. Trends Biochem Sci 38: 177-183.

Liu Y, Olanrewaju YO, Zheng Y, Hashimoto H, Blumenthal RM, Zhang X, Cheng X. 2014. Structural basis for Klf4 recognition of methylated DNA. Nucleic Acids Res 42: 4859-4867.

Nakagama H, Heinrich G, Pelletier J, Housman DE. 1995. Sequence and structural requirements for high-affinity DNA binding by the WT1 gene product. Mol Cell Biol 15: 1489-1498.

Okano M, Xie S, Li E. 1998. Cloning and characterization of a family of novel mammalian DNA (cytosine-5) methyltransferases. Nat Genet 19: 219-220.

Otwinowski Z, Borek D, Majewski W, Minor W. 2003. Multiparametric scaling of diffraction intensities. Acta Crystallogr A 59: $228-234$.

Ozdemir DD, Hohenstein P. 2014. Wt1 in the kidney-a tale in mouse models. Pediatr Nephrol 29: 687-693.

Pagel JI, Deindl E. 2011. Early growth response 1-a transcription factor in the crossfire of signal transduction cascades. Indian J Biochem Biophys 48: 226-235.

Pavletich NP, Pabo CO. 1991. Zinc finger-DNA recognition: crystal structure of a Zif268-DNA complex at 2.1 A. Science 252: 809-817.

Persikov AV, Singh M. 2014. De novo prediction of DNAbinding specificities for Cys2His2 zinc finger proteins. Nucleic Acids Res 42: 97-108.

Quenneville S, Verde G, Corsinotti A, Kapopoulou A, Jakobsson J, Offner S, Baglivo I, Pedone PV, Grimaldi G, Riccio A, et al. 2011. In embryonic stem cells, ZFP57/KAP1 recognize a methylated hexanucleotide to affect chromatin and DNA methylation of imprinting control regions. Mol Cell 44: 361-372.

Ritchie MF, Yue C, Zhou Y, Houghton PJ, Soboloff J. 2010. Wilms tumor suppressor 1 (WT1) and early growth response 1 (EGR1) are regulators of STIM1 expression. I Biol Chem 285: 10591-10596.

Sasai N, Nakao M, Defossez PA. 2010. Sequence-specific recognition of methylated DNA by human zinc-finger proteins. Nucleic Acids Res 38: 5015-5022.

Sharif J, Muto M, Takebayashi S, Suetake I, Iwamatsu A, Endo TA, Shinga J, Mizutani-Koseki Y, Toyoda T, Okamura K, et al. 2007. The SRA protein Np95 mediates epigenetic inheritance by recruiting Dnmt1 to methylated DNA. $\mathrm{Na}$ ture 450: 908-912. 
Stoll R, Lee BM, Debler EW, Laity JH, Wilson IA, Dyson HJ, Wright PE. 2007. Structure of the Wilms tumor suppressor protein zinc finger domain bound to DNA. I Mol Biol 372: 1227-1245.

Tahiliani M, Koh KP, Shen Y, Pastor WA, Bandukwala H, Brudno Y, Agarwal S, Iyer LM, Liu DR, Aravind L, et al. 2009. Conversion of 5-methylcytosine to 5-hydroxymethylcytosine in mammalian DNA by MLL partner TET1. Science 324: $930-935$.

Wolfe SA, Nekludova L, Pabo CO. 2000. DNA recognition by Cys2His2 zinc finger proteins. Annu Rev Biophys Biomol Struct 29: 183-212.

Yu M, Hon GC, Szulwach KE, Song CX, Zhang L, Kim A, Li X, Dai Q, Shen Y, Park B, et al. 2012. Base-resolution analysis of 5 -hydroxymethylcytosine in the mammalian genome. Cell 149: $1368-1380$. 


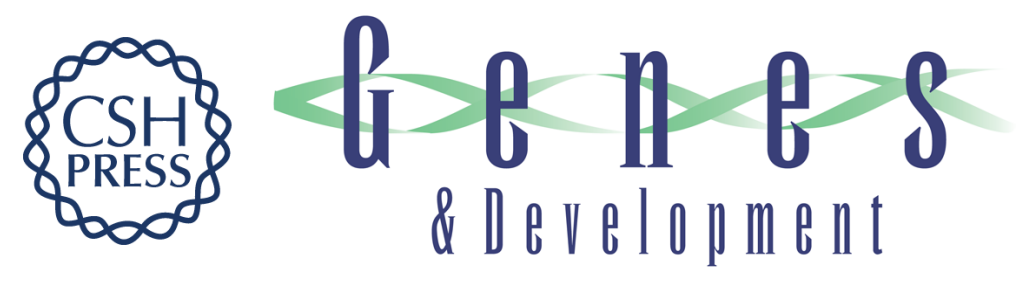

\section{Wilms tumor protein recognizes 5-carboxylcytosine within a specific DNA sequence}

Hideharu Hashimoto, Yusuf Olatunde Olanrewaju, Yu Zheng, et al.

Genes Dev. 2014, 28: originally published online September 25, 2014

Access the most recent version at doi:10.1101/gad.250746.114

\section{Supplemental http://genesdev.cshlp.org/content/suppl/2014/10/09/gad.250746.114.DC1 Material}

References This article cites 40 articles, 12 of which can be accessed free at: http://genesdev.cshlp.org/content/28/20/2304.full.html\#ref-list-1

Creative This article, published in Genes \& Development, is available under a Creative Commons Commons License (Attribution 4.0 International), as described at License http://creativecommons.org/licenses/by/4.0.

Email Alerting Receive free email alerts when new articles cite this article - sign up in the box at the top Service right corner of the article or click here.

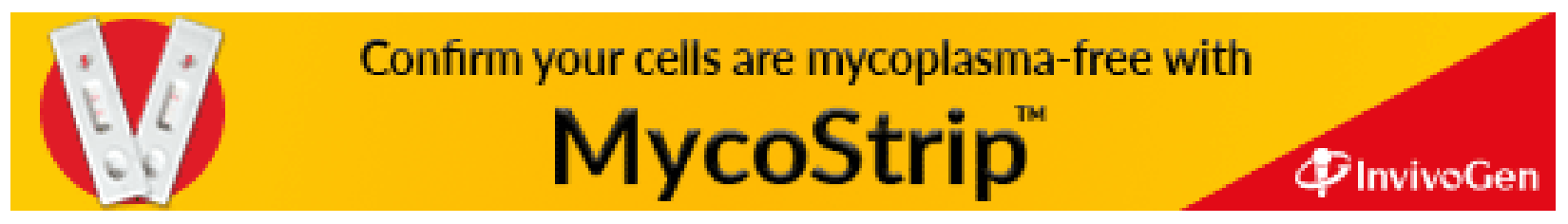

